\title{
The Concept of Kempel in Mantram Reciting Found in Ruwatan Murwakala
}

\author{
Agus Efendi ${ }^{1}$, R Adi Deswijaya ${ }^{2}$ \\ $\left\{\right.$ kambang.leng2@yahoo.co.id $\left.{ }^{1}\right\}$ \\ ${ }^{12}$ Veteran Bangun Nusantara University of Sukoharjo
}

\begin{abstract}
Ruwatan rite usually held by Javanese people until today is the realization of cultural laku (behavior), believed to be an attempt of avoiding an individual from disaster threat portended. This article aims at describing the elements consisted in the process of reciting mantram in Ruwatan Murwakala with its magical power. This is a descriptive qualitative research using interview, observation and library study. The research finds that the reciting of mantram in ruwatan performance has magical power if there is Kempel or unity between the elements of its formation and its functions such as the way of mantram/mantra pronunciation, the music applied, the silence built by dhalang (puppeteer) ruwat and the use of properties during the performance like burning the incense, low sound using, and the figure of dalang ruwat with his spiritual competence.
\end{abstract}

Keywords: kempel, mantram, ruwatan murwakala, magic, ritual

\section{Introduction}

Wayang (puppet) art is a traditional performance presented by a dhalang (narrator) using doll or the similar as the performing instrument [1], [2]. This wayang performing media is believed to bridge the dedication to ward off disaster, with a performance usually called ruwatan [3]-[6]. The word ruwat appeared in Kunjarakarna book in the sentence pamalakurinuwan mala nyanten i nghulun" meaning "please clear my little sibling's stain away" [7]. Rumuwat or mangruwat means disabling, removing, relieving, escaping from sukerta [8], [9]. Considering the existence of ruwatan tradition known since Majapahit period, it belongs to local wisdom of Javanese people. Local wisdom [10] is any form of knowledge, belief, understanding or insight, and custom or habit or ethic In the performance of ruwatan Murwakala ritual with shadow puppets will relate to sacred matters mostly during the reciting of mantram in the ruwatan ceremony[11]-[13]. The reciting of mantram starts in the scene where Bathara Kala meets with puppeteer character called Kandha Buana. Puppeteer character, Kandha Buana reads the inscriptions in Bathara Kala's body such as under skin,chest, spine, forehead and oral cavity. Those inscriptions in the puppetry is known as sastra dhadha, sastra gigir, satra bathuk, and sastra pedati. After the puppeteer, kandha buana finishes the reciting all the inscriptions, he continues reciting ruwatan mantram consisted 11 mantrams. 
The use of mantrams in ruwatan Murwakala in the puppetry such as sabet, catur and iringan can cause the sanctity during the show. Ruwatan can build a magical energy and cause the existence of trust toward the essence of mantra/mantram. Developing trust takes long time, acculturation in the society, implementation. Reciting mantra in Ruwatan Murwakala will touch the feeling and will influence the society if there is a wholeness in its performance done by Ruwat Puppeteer with Kempel concept.

Several studies have been conducted on ruwatan, for example, Soetarno's study entitled “Wayang Kulit: The Change of Meaning and Entertainment” [14], Subalinata et al.'s "History and Development of Murwakala Story from Javanese Letter Sources" [7], Harpawati's entitled "Wayang Kulit Purwa Performance with Lakon Sudamala as the Selamatan ritual tradition in Javanese people's life" (2017), Sarwanto's entitled "The Performance of Wayang Kulit Purwa Jawa in Bersih Desa Ritual, a study on function and meaning” [2], and Lestari's entitled "Ethical Value of Ruwatan Sukerta with Wayang Kulit Purwa performance, its relevance to People's Noble Character Inculcation" [15].

However, those studies have not discussed ruwatan tradition viewed from the constructive element needed to make the circumstance having sacred nuance and magic power when the spellings are read in the ruwatan.

\section{Research Method}

This study was a descriptive qualitative research, recalling that the data collected constituted words, sentences, or images having meaning more than figure (number). A qualitative research could give a complex detail on the phenomenon difficultly revealed by the quantitative (statistic) one. The author emphasized on the notes representing actual situation to support data presentation. The author also attempted to analyze data with all of his nuanced character vocabularies, as closely as possible to the original form just like when the spelling is recorded (noted).

This type of study was chosen recalling the possibilities to be faced by a plural reality during the research period, in which reciprocal interaction between author and the topic studied is very important to facilitate the searching for meaning depth. This characteristic is more sensitive and adjustable with the study on the forms of effect and the pattern of values potentially encountered [16].

This research on ruwatan case not only developed knowledge through speculative construction but also captured the meaning of knowledge through the presence of data in character consciousness. This approach is called phenomenological approach.

\section{Results And Discussion}

Overall, the result of research relates to the circumstance when antra (spelling) is uttered in ruwatan Murwakala performance, particularly in the scene between the narrator Kandha Buwana and Bathara Kala. In a context, ruwatan performance can construct the magic power constructed by dhalang ruwat so far by integrating some elements into a single concept, kêmpêl, including among others: (1) puppetry utensil element (sabet, catur and accompaniment); (2) recommendation regarding mantram (spelling) power given by dhalang 
ruwat to the spectators, (3) incense burning; and (4) recommendation that microphone sound should be shut down or lowered.

Ruwatan ceremony is a system of rite developed by Javanese society. Ruwatan ceremony usually held by the Javanese society up to now is the realization of culture. It is believed as an effort to avoid someone from danger [17]. In Baoesastra [18] it is explained that etymologically, ruwatan is similar to Luwar means free in Javanese context. The word Ruwatan is derived from the root WAT, means escape or free. Ruwatan is similar to the sanctification in ritual salvation. In Javanese [19] adds the term Ruwat in Old Javanese is close to wwat meaning "jemabatan (bridge)" and "mempersembahkan (present)". It is to bridge someone to free from danger and magical energy. We can find a whole system and unity such as ceremony equipment, puppeteer, ruwat, sajen, matraman, sukerta, ruwatan ceremony process, Murwakala in the shadow puppet show.

Mantra/mantram is the most important aspect in Ruwatan ceremony. Mantra in Indonesian [18] dictionary means utterance or sentences that can bring the magical energy. Ruwatan Murwakala show uses mantraman such Sastra batuk (caraka balik), Sastra dada (sastra bedati), Sastra telak (huruf dilangit-langit mulut) dan Sastra gigir (huruf di punggung), mantram wiwitan, mantram siraman etc.

In its implementation, the puppeteer will tell the host to forbid the girls watching and the pregnant grand daughter to watch the show when the mantra is read since the mantra can put them in danger [7]. Firstly, Ruwat puppeteer instructs the pregnant audience to leave the place where the ruwatan ceremony with shadow puppet entitled Murwakala is held. It is believed that there will be magical energy in mantram read in ruwatan ceremony. The puppeteer asks to turn down the volume of the sound system. This situational context shows that mantras in Ruwatan is very inclusive and secret. Only the puppeteer and certain people have the right to know the mantra of Ruwat Puppeteer. This is due to convince the cultural supporters and Ruwatan ritual that there is a magical energy within the mantra recited.

The faith on what the Javanese society have believed as the absolute achievement in mantram recital requires the puppeteer to turn all the lamps and sound system off. This fits to the theory about how the system of myth is shaped [20]. The myth is shaped because of the existence of signs in the reciting mantrams Ruwatan that is presented through the verbal acts of the puppeteer.

In the semiology process analysisn, there are mantarm having poem elements (dentative) as a signifiant. In Barthes' semiology explains denotative is significant construction in the first phase while the connotative is on the second phase. However, in Javanese community, this mantra is believed to have a magical energy based on the situational function.

Myth is a special system shaped from a series of semiology chains [21]. It means that myth is the second semiology system. The sign in this myth is the combination of concept and image. The researcher uses semiotics theory considering that all phenomena in society and culture are signs [22]. In this case, the sign is tradition in Ruwatan.

The magical elements in Ruwatan Murwakala show is an applicative action of a myth. Based on semiotics, myth is a symbol and human is a subject as interpreter of the symbols. However, ontology study thinks that the magical energy is closely related to cosmology metaphysic.

In the mantras recital, especialy in the scene where Bathara Kala with puppeteer, Kandha Buana, the puppeteer uses Javanes music, Ladrang Eling-eling. Ladrang Eling-eling or Ayakayak dhendo slendro mayuro with calm characteristic. The atmosphere is better in appreciation because of the use of calm music and the puppeteer sings the mantram with the tunes. This makes the scene has sacred concept, moreover when it is accompanied by the 
smell of burning incense. The sanctity of a ceremony is believed as an achievement. The appearance of the sanctity is found in the ritual activities. Ritual ceremony is believed as a way to search safety, to avoid danger, to find prosperity and peace. Ruwatan Murwakala show with its sacred ritual inspires the beauty and it is meaningful for life goal.The atmosphere on Ruwatan Murwakala show consists of sanctity as a part of ritual. The use of sajen, the different setting of stage of Ruwatan puppet show and usual shadow puppet, and the burning of incense recital of prayers confirm that there is strong magical energy in ruwatan puppet show. The sanctity made from many elements is a process that can give us the success. The recital mantra or mantram with prayers is able to influence the nature.

Esthetic values in Ruwatan Murwakala show with shadow puppets consists of a kempel concept or unity in reality. Unity means that a work of art based on art rules and has perfect image. Structurally, the relation among its elements is suitable with its function. Aesthetic in art show refers to how the puppeteer of Ruwat [8]. It can be caused by ability of each puppeteer to present the problems of the characters. To find a maturity in playing his rules as Ruwat Puppeteer, in Javanese culture there is a term anut kadewasaning yuswa 'following maturnity of age of experience, appreciation, and competence of the puppeteer.

Ruwatan show cannot only tells about the story, characters, or music. When the discussion refers to specifically to dramatic performance of shadow puppet, in this case is Ruwatan Murwakala show, so we cannot avoid that the puppeteer must master knowledge and all supported elements in ruwatan ceremony.

Sabet is the main part of puppetry utensils defined as anything related to wayang movement [23]. The movement of wayang in ruwatan Murwakala performance needs skill related to wayang movement, including Tancep, capeng, Ulap-ulap and walking, abur-aburan, and the movement of non-character and animal. Wayang movement needed included the movement following the plot of story or scene, particularly tancepan wayang. In this case, particularly the scene between characters of dhalang (narrator) Kanda buwana sitting on pelemehan or two banana stems as the tancepan medium or a place for sticking the wayang and other character, the character as the personification of the one holding the event, bocah sukerta and bathara Kala. The position of tancepan needed by character dhalang Kandabuwana should be stuck into upper pelemehan and other character stuck into the lower pelemehan. This condition implies that everyone present in the scene respects and trusts in dhalang kandha buwana for he can give solution to the problem faced.

Ginem, according to Soetarno, is divided into two: ngudarasa or mumbling or monologue or dialogue with more than one character [24]. Pocapan/illustration of dhalang represents or describes state, name of king, king's soldier, predisposition of character and etc without karawitan accompaniment but supported with the sound of dhodhogan (resulting from the sound of wayang kit hit using Cempala) or keprak sound. In the dialogue of scene between character dhalang Kandha Buwana when facing the one holding the event, bocah sukerta or Bathara Kala is more dominant than narrator (dhalang) Kandha Buwana believed to be an individual that can solve problem and can do ruwatan and subjugate Bathara Kala. In the scene, the character of narrator Kandha Buwana is wise, as indicated with the tone of dialogue seeming to be patient and wise. Janturan is the dhalang's illustration describing state, name of king, king soldier, predisposition of character and etc. accompanied with karawitan pakeliran in the form of sirep [25][26]. The illustration used by the narrator of ruwat (dhalangruwat) to describe the circumstance where ruwatan is held and characterization, particularly the characterization of narrator Kandha Buwana and Bathara Kala is then used as well to describe the condition of ruwatan, to be used later to describe the condition of ruwatan place and terrible circumstance when the character Bathara Kala is present. 


\section{Conclusion}

Ruwatan Murwakala show with shadow puppet as its media can be believed as a ritual ceremony having magical energy or power, moreover when the puppeteer recites the mantra/mantram. This scene consists of sacred element that can be made from specific elements such as sabet, catur, iringan (music) and other property (burning incence, ruwat puppeteer's requirement about the power of mantra/mantram)

\section{Reference}

[1] S. Wibisono, "Wayang sebagai Sarana Komunikasi," Prisma, vol. III, no. 3, p. 6, 1974.

[2] Sarwanto, "Sekilas Tentang Perkembangan Pertunjukan Wayang Kulit di Jawa dari Masa ke Masa, Sebuah Tinjauan Historis," LAKON, vol. IV, no. 1, 2007.

[3] A. Efendi, A. Purwasito, B. Sudardi, and W. Abdullah, "DHALANG SEJATI : THE LEGACY OF CULTURAL HEGEMONY IN RUWATAN CEREMONY," Int. J. Soc. Sci. Econ. Res., vol. 3, no. 5, pp. 1756-1767, 2018.

[4] Darmoko, "RUWATAN: UPACARA PEMBEBASAN MALAPETAKA TINJAUAN SOSIOKULTURAL MASYARAKAT JAWA," MAKARA, Sos. HUMANIORA, vol. 6, no. 1, pp. 30-36, 2002.

[5] Rahmat, "MAKNA LEKSIKAL DAN MAKNA GRAMATIKAL :," LITERASI, vol. 5, no. 2, pp. 150-157, 2015.

[6] H. Wahidah and Akhmad Jazuli Afandi, "The Social - Political Significance of Ruwatan Desa Ritual," Reli. J. Stud. Agama-agama, vol. 8, no. 2, pp. 280-302, 2018.

[7] Subalidinata, "Cerita Murwakala dan Ruwatan di Jawa." Javanologi, Yogyakarta, 1985.

[8] A. Efendi, A. Purwasito, B. Sudardi, and W. Abdullah, "Pragmatic Study of Discourse Hegemony on the," KOMUNITAS Int. J. Indones. Soc. Cult., vol. 8, no. 2, pp. 199-207, 2016.

[9] K. Saddhono and A. Hartarta, "THE STUDY OF TYPE AND MEANING OF JAVANESE INDONESIAN," ASIAN J. Soc. Sci. Humanit., vol. 2, no. 1, pp. 51-58, 2013.

[10] D. B. P. Setiyadi and C. Java, "DISCOURSE ANALYSIS OF SERAT KALATIDHA: JAVANESE COGNITION SYSTEM AND LOCAL WISDOM," ASIAN J. Soc. Sci. Humanit., vol. 2, no. 4, pp. 292-300, 2013.

[11] J. Lynch et al., "Impact of mantra meditation on health and wellbeing: A systematic review protocol," Eur. J. Integr. Med., vol. 18, no. November 2017, pp. 30-33, 2018.

[12] S. Leary, K. Weingart, R. Topp, and J. Bormann, "The Effect of Mantram Repetition on Burnout and Stress Among VA Staff," Workplace Health Saf., vol. XX, no. X, pp. 1-9, 2017.

[13] L. Aragon, "Missions and omissions of the supernatural: Indigenous cosmologies and the legitimisation of "religion' in Indonesia," Anthropol. Forum A J. Soc. Anthropol. Comp. Sociol., vol. 13, no. December 2014, pp. 37-41, 2010.

[14] Soetarno, "Wayang Kulit: Perubahan Makna Ritual dan Hiburan. [Puppet Leather: the Change between the Ritual and enternaiment Meanings]." STSI Press, Surakarta, 2004.

[15] W. Lestari, "Nilai Etis Ruwatan Sukerta dalam Pertunjukan Wayang Kulit Purwa: Relevansinya Bagi Penanaman Budi Pekerti Masyarakat.” Disertasi pada Program Studi Ilmu Filsafat, Jurusan Ilmu-Ilmu Humaniora, Program Pascasarjana Universitas Gadjah Mada Yogyakarta, Yogyakarta, 2009.

[16] H. . Sutopo, "Metodologi Penelitian Kualitatif: Dasar Teori dan Terapannya dalam Penelitian." Sebelas Maret University Press, Surakarta, p. 35, 2002.

[17] Koentjaraningrat, "Kebudayaan Mentalitet dan Pembangunan." PT Gramedia, Jakarta, 1974.

[18] W. J. . Poerwodarminto, "Baoesastra Tjilik." Groningen, Batavia, 1939.

[19] Zoetmulder, "Kamus Jawa Kuna-Indonesia." Gramedia Pustaka Utama, Jakarta, 2004.

[20] R. Barthes, "Mythologies." The Noonday Press, New York, 1975.

[21] R. Barthes, "Membedah Mitos-mitos Budaya Massa; Semiotika atau Sosiologi Tanda, dan 
Representasi (terjemahan Ikramullah Mahyudin).” Jalasutra, Yogyakarya, 2006.

[22] D. Rusmana, "Filsafat Semiotika; Paradigma, teori, dan metode interpretasi tanda dari semiotika struktural hingga dekontruksi praktis." Pustaka Setia, Bandung, 2014.

[23] Soetarno, "Estetika Pedalangan.” ISI Surakarta dan CV Adji Surakarta, Surakarta, 2007.

[24] B. Murtiyoso, "Pengetahuan Pedalangan." Proyek Pengembangan IKISub ProyekASKI, Surakarta, 1980.

[25] Kasidi, "Estetika Pedalangan Ruwatan Murwakala: Kajian Estetika dan Etika Budaya Jawa." ISI Yogyakarta, Yogyakarta, 2017.

[26] K. Saddhono, "Language of Coastal Communities in the Northern Coast of Central Java: Sociolinguistic Studies in Cultural Integration Maritime-Agrarian Perspective." Adv. Sci. Let. vol. 23 no.10 pp 10054-10056, 2017 